Nota Bene: Canadian Undergraduate Journal of Musicology

Volume 12 | Issue 1

Article 3

\title{
Magic and Enlightenment auf der Weisen: Der Stein der Weisen and Die Zauberflöte
}

Mercer Greenwald

Bard College Conservatory of Music

\section{Recommended Citation}

Greenwald, Mercer. "Magic and Enlightenment auf der Weisen: Der Stein der Weisen and Die Zaouberflöte." Nota Bene: Canadian Undergraduate Journal of Musicology Vol. 12, no. 1 (2019): 30-45. https://doi.org/10.5206/notabene.v12i1.8145 


\title{
Magic and Enlightenment auf der Weisen: Der Stein der Weisen and Die Zauberflöte
}

\begin{abstract}
This paper probes how the rational and the irrational interact in Enlightenment operatic plots, and explores the effect of this interaction on the Viennese public. To do this, I will investigate the fantastic worlds of two operas premiered by the same opera company, both with libretti written by Emanuel Schikaneder: Der Stein der Weisen oder Die Zauberinsel (1790) and Die Zauberflöte (1791). David J. Buch's seminal book Magic Flutes and Enchanted Forests (2008) explores the intertextual threads of magical ideas in Der Stein der Weisen and Die Zauberflöte, that is, how librettists and composers translated and reprocessed magical themes. I will draw on Buch's comparison to show how these intertextual connections can be read for their broad cultural resonances. In this paper, I will first establish the connections between Der Stein der Weisen and Die Zauberflöte in plot and in music. Then I will show how the later opera diverges from its predecessor and discuss how it manages to diminish the polarity of rationality and irrationality considered central to Enlightenment thinking. Ultimately, I argue, Die Zauberflöte facilitates its audience's access to Enlightenment values by magical means.
\end{abstract}




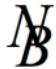

\section{Magic and Enlightenment auf der Wieden: Der Stein der Weisen and Die Zauberflöte}

\section{Mercer Greenwald \\ Year II - Bard College Conservatory of Music}

The audience of Vienna's Theater auf der Wieden swooned as Nadine sang to magical birds, rejoiced when Tamino summoned Pamina with his magic flute, dissolved into laughter as Lubanara meowed like a cat, and quivered as the Queen of the Night descended onto the stage from above. In an era of Enlightenment rationality, the folk-based worlds of Der Stein der Weisen oder Die Zauberinsel (1790) and Die Zauberflöte (1791) seemed to be, counterintuitively, steeped in magic, exoticism, and irrationality. Magic flutes and philosopher's stones, and all of their many magical permutations, are emblematic of the complexities found in the work of Enlightenment operatic composers and librettists, and these supernatural themes are crucial to shaping the balance of the rational and irrational forces within the Viennese eighteenth-century ethos.

Der Stein der Weisen is a Singspiel in two acts, composed by Johann Baptist Henneberg, Benedikt Schack, Franz Zaver Gerl, Emanuel Schikaneder, and Wolfgang Amadeus Mozart. The libretto for this Singspiel was written by Schikaneder, who based the 
story on Wieland's 1786 Dschinnistan fairy tale collection. ${ }^{1}$ Though the title of Schikaneder's libretto derives from the collection's last tale, it shares more elements with the first story, "Nadir und Nadine." 2 In order to align the story with the commedia dell'arte tradition, Schikaneder simplified the plot of "Nadir und Nadine," added a pair of comic lovers, and included a shipwreck that left the characters stranded on a deserted island. ${ }^{3}$ Performances of Der Stein continued for about ten years after its premiere and then vanished from the repertoire. Just one year after the Der Stein premier, the same librettist and singers took on parallel roles in Die Zauberflöte. Schack, who had sung the part of Astromonte, sang Tamino; Gerl (Eutifronte) sang Sarastro; Urban Schikaneder (Sadik) sang the first priest; Johann Michael Kistler (Nadir) sang the second priest; Anna Gottlieb (Nadine) sang Pamina; Emanuel Schikaneder (Lubano) sang Papageno; and Barbara Gerl (Lubanara) sang the part of Papagena. ${ }^{4}$ Henneberg, once again led the orchestra from the piano in Die Zauberflöte, just as he had in Der Stein. Mozart and Schikaneder reference the musical and literary themes that would still have been fresh in audiences' minds from Der Stein.

There is no question that the two operas are closely connected. Both premiered on the same stage and made use of the technological aids that were available, such as flying machines, lifts, swift transformations, special lighting effects including

1. Peter Branscombe, Die Zauberflöte (Cambridge: Cambridge University Press, 1991), 144.

2. David J. Buch, "Introduction" in Der Stein der Weisen (Middleton: A-R Editions, 2007), xiii.

3. David J. Buch, Magic Flutes and Enchanted Forests, (Chicago: University of Chicago Press, 2008), 334.

4. Branscombe, Die Zauberflöte, 145-52. 
impressively lifelike waterfalls and infernos. ${ }^{5}$ The operas each contain comic scenes with characters who cannot speak and include instances where a group of women argue over who is the most innocent. Each work also features contrasting pairs of lovers, a supposedly evil character who captures a young princess but turns out to be good, and a scene where one character is rescued from suicide. The two sets of lovers have matching names and social positions; in each work, one couple is of a high societal status while the other is of a lower status.

The two operas are similar not only in their plots and themes but also in their music; it is almost as if Die Zauberflöte used Der Stein as its template. Each work has a two-act structure with an introduction and a grand and episodic finale. The musical numbers in each integrate the solemn and the comic, as was the custom in other Mozart operas. ${ }^{6}$ In each work, the second act begins with syncopated alla roppa rhythms (Excerpt 1), passed among the strings, winds, and brass. Der Stein and Die Zauberflöte both contain enchanted march music introduced by the winds. Both operas also feature instances where descending octave leaps introduce magical characters (Excerpt 2a) and lead to a bipartite aria ending in a Bflat allegro coloratura number (Excerpt 2b). Perhaps because the two works made use of many of the same cast members, both the composers of Der Stein and Mozart with Die Zauberflöte arranged for the music to showcase each voice in similar ways. For instance,

5. David Cairns uses the complex stage technology as evidence for his argument that: "Mozart, evidently, was not writing for a second-rate band." Mozart and His Operas (Berkeley: University of California Press, 2006), 202.

6 . These operas are intertextual in their respective integrations of seria and buffa themes. Serious and comic operas were never completely polarized. Mary Hunter explains that: "opera buffa is, in other words, a fundamentally intertextual genre." Mary Hunter, "Some representations of opera seria in opera buffa," in Cambridge Opera Journal (New Haven: Yale University Press, 2008), 90. 
both operas include an aria to show off Schikaneder's comic character after the introduction and just before the Act 2 finale. Both Lubano's and Papageno's arias have substantial trill motives that extend the phrase to the cadence. Soprano Anna Gottlieb was given a despairing aria in both productions. Nadine and Pamina's arias are introduced with legato wind lines and accompanied by duple eighth-notes in the strings.

Despite the countless formal similarities between these two operas, their effects are quite different, not least because Mozart composed the music for Die Zauberflöte completely himself, whereas he was merely a collaborator on Der Stein. The music of Die Zauberflöte operates at a more sophisticated level than that of Der Stein. The orchestration, for instance, is richer and more varied. This richness is achieved through counterpoint; for example, in Die Zauberflöte, the voices are less vertically aligned and more intertwined. Schikaneder's Die Zauberflöte text mirrors this higher level of musical sophistication in its use of more streamlined and cultivated poetic conventions. Branscombe notes, for instance, that Papageno's entrance song is composed of iambic four-beat lines, Sarastro's second aria is composed of iambic three-beat lines, and the Queen's aria is in iambic pentameter. Tamino's aria “Dies Bildnis ist bezaubernd schön" is a sonnet, and the musical qualities of the sonnet's motion lends itself well to Mozart's harmonies. ${ }^{7}$ In the first quatrain, Mozart opens with E-flat tonal configurations and then modulates the harmonies into the key of B-flat for the second quatrain. In the first tercet, Mozart incorporates chromatic movement which intensifies the passion of Tamino's emotion, and then he returns to the key of E-flat for the final tercet. This array of keys functions to bring sonata form-with an exposition, a

7. Branscombe, Die Zauberflöte, 102. 
development, and a recapitulation — into the aria's harmonies. This harmonically driven order, which returns to the primary key of the opera, is nothing short of sublime. Both Tamino's aria and Die Zauberflöte, as distinguished from Der Stein, have the ultimate effect of contrapuntal and harmonic complexity.

As narratives, Der Stein and its successor Die Zauberflöte share remarkable similarities: both are magical rescue stories rich in exotic topoi in both music and text. However, Der Stein may be distinguished from Die Zauberflöte in the clear-cut comedic linearity of its plot: the opera outlines a progression from ignorance to knowledge and immaturity to maturity. Because Der Stein is no longer part of the modern repertoire, I will proceed to discuss the opera's plot in depth.

Der Stein begins with a disruption of the existing order on a deserted island. When Sadik, the island's ruler, attempts to conduct a sacrifice to the spirit Astromonte, the ceremony is delayed by the mischief of his two foster children: the lovers Nadir and Nadine, and their friends Lubano and Lubanara. When Astromonte appears, he is accompanied by a pair of flutes playing parallel thirds and a magic bird. The bird sings that it will find the most virtuous maiden for Astromonte to take as his new wife. This maiden turns out to be Nadine, and Astromonte sweeps her away. This disruption of the initial order inspires a mission to set things right, and Nadir sets out to sea with the Arcadians to rescue his beloved. Paradoxically, the goal to restore the pre-existing status quo simultaneously establishes chaos in the opera's plot. In Act Two, the evil spirit Eutifronte convinces Nadir that he must murder Astromonte in order to save Nadine; Nadir works together with Lubano and Lubanara to achieve this goal. Just as the plotdriven chaos is on the verge of irreconcilable despair, Astromonte appears in the disguise of an old man holding a bird and ties 
together all of the plot's problems: Astromonte magically brings back Nadine and reveals that he is Nadir's long-lost father. It becomes clear that Astromonte was testing Nadir all along in order to confirm his loyalty. As soon as Nadir proves himself, eagles fly overhead and drop down the prophetic Philosopher's Stone, declaring Nadir the worthy son of Astromonte. In the opera's finale, order is restored: Astromonte takes back his own shape, Eutifronte sinks down into the abyss, Nadir and Nadine are married, and the Arcadians rejoice.

The plot described above lays the groundwork for Die Zauberflöte in several ways, but with key differences. Both operas are structured around a dichotomy between good and evil, but whereas this dichotomy in Der Stein remains consistent throughout the work, it reverses in the middle of Die Zauberflöte. In Der Stein, the audience is aware of the polarization between Astromonte and Eutifronte from the beginning. Although it is not completely clear if Astromonte's intentions are good, Eutifronte is a blatantly malevolent figure. In Die Zauberflöte, the Queen of the Night appears to be the good figure whose daughter is stolen by the seemingly evil Sarastro; however, our understanding of good and evil is reversed over the course of the opera. In particular, it is revealed that the Queen is in fact the antagonist. The two plots differ in the way that they align good and bad characters, and they also differ in their respective approaches to magic. On the surface, the magical elements of each opera seem more or less identical. Magic accompanies both Nadir and Tamino on their paths to leadership, and each go through a series of supernatural trials to reach their beloved. In this respect, both plots contain fairy tale conventions, since, as Maria Tatar writes, "Metamorphosis is central to the fairy tale, which shows us figures endlessly shifting 
their shapes, crossing borders, and undergoing change." ${ }^{8}$ David Buch identifies this "change" when he argues that Nadir and Tamino "first must learn to rule [their] own emotions before [they] can rule others." But whereas Nadir develops through maturation alone, Tamino must additionally undergo a process of philosophical education.

It is in the trajectory of its plot that Die Zauberflöte diverges most profoundly from Der Stein der Weisen. While the magical narrative of Der Stein presents itself as an amusing linear progression, the story of Die Zauberflöte throws linearity into question. At the beginning, we are presented with all the makings of a purely linear narrative with comedic undertones: there is a clearly evil character, a problematic event, and an apparent hero who is poised to solve the problem, aided by helpful characters along the way. When Tamino, our hero, learns that an 'evil' king took the beautiful princess Pamina from her 'innocent' mother, he sets out to rescue her with his comedic sidekick, Papageno. Sarastro's minions, however, hinder their rescue journey. When Tamino and Papageno finally encounter Sarastro, this cohesive linear narrative is complicated, and its configuration of good and evil is ultimately reversed. The new narrative takes the equally linear form of a series of trials; these trials test Tamino and Pamina's ability to demonstrate the enlightened, rational practices of self-control and delayed gratification. ${ }^{10}$ When Tamino and Pamina emerge from their series of tests, they see the world differently. Tamino, Pamina, and their audiences realize that

8. Maria Tatar, "Why Fairy Tales Matter: The Performative and the Transformative," in Western Folklore 69 (2010), 55.

9. Buch, Magic Flutes, 337.

10. Nicholas Till, Mozart and the Enlightenment: Truth, Virtue, and Beauty in Mozart's Operas (New York: Norton, 1996), 72. 
Sarastro actually possesses the qualities of a truly wise leader, while the Queen herself is relegated to the realm of the irrational. What was once dark is illuminated, and perhaps more importantly, what was light is now dark; thus, we see that one undeviating narrative is replaced by another, and as a result, the very notion of linearity in this opera is disrupted.

One could make the argument that overall, Die Zauberflöte does indeed follow a linear trajectory toward the Enlightenment values of self-reflection restraint, and humanity. Tamino and Pamina are quintessential Enlightenment protagonists: despite the fact that they are prince and princess, they share qualities with their bourgeois audiences. At the end of the opera, they marry and ascend to Sarastro's throne. They have passed their tests and are prepared to serve as enlightened figures. But on the other handif we understand this opera as a progression from darkness to illumination, or from superstition to rationality-then this progression is left unresolved, specifically with relation to Papageno. Although Papageno tells Tamino that he is "ein Mensch, wie du," his humanity is not enough to transform him into a fully realized Enlightenment figure like Tamino. ${ }^{11}$ Mladen Dolar explains that this is due to the fact that both Papageno and other characters "are satisfied with their subordination." 12

Papageno's metamorphosis is different than Tamino's because Papageno is so closely connected to the world of nature and magic. In this respect, we might imagine him to be more fully aligned with the world of Der Stein, which is, for all intents and

11. Wolfgang Amadeus Mozart, Die Zauberflöte KV 620 (Basel: Bärenreiter Kassel, 2017), 73.

12. Mladen Dolar, "If Music Be the Food of Love," in Opera's Second Death, ed. Slavoj Zizek and Mladen Dolar (Oxford: Oxford University Press, 2002), 83. 
purposes, a fairy tale. Die Zauberflöte, on the other hand, is usually read as an allegory of Enlightenment. So then how do we account for Sarastro's inclusion of Papageno in the festivities, despite the fact that Papageno cannot achieve the philosophical illumination that Tamino does? Nicholas Till describes the way Mozart incorporates an "integrated complexity of classicism in favour of a sometimes almost childlike simplicity of expression" in Papageno's music. ${ }^{13}$ Charles Rosen also makes note of the way Mozart renounced "harmonic color" and "dispensed with sonata form" in his portrayal of Tamino's simplicity. ${ }^{14}$ This renunciation of colour and complexity also applies to Papageno's music, the opera's simplest music. Papageno's musical accessibility may also reflect what Till notices in the opera as a whole_-namely, the "longing of those who had become distrustful of the public and political realm" to "retreat from political engagement" after Joseph II clamped down on public debate and reintroduced censorship of the press in the last year (1790) of his reign. ${ }^{15}$ Perhaps as a mode of this very retreat, Papageno's pipes offer an alternative to excessive public posturing; they do away with the sublime sonata form and offer a sound of beautiful, childlike purity. Whereas the Three Child-Spirits (Die drei Knaben) give Tamino his flute to help him achieve transcendent political ideals, Papageno's pipes belong to the natural world that he himself inhabits, and he uses them only for survival and enjoyment. Even when the Three Child-Spirits give Papageno the Magic Bells, he does not play them with the same virtuosity with which Tamino plays his magic flute; instead, Papageno's bells sound just as simple as the pipes he plays every day. The fact that Papageno does not fulfill all of the tasks set

13. Till, Mozart and the Enlightenment, 270.

14. Charles Rosen, The Classical Style (London, 1974), 254.

15. Till, Mozart and the Enlightenment, 270. 
before him does not cause his audience to adore him any less; on the contrary, it is his music that has become the hallmark of the opera.

Throughout the seventeenth and eighteenth centuries, magic themes in Viennese Singspiel were disregarded as an unenlightened trend of escapism primarily for the lower classes. Till supports this idea in his description of the "retreat from public engagement" during the reign of Joseph II. ${ }^{16}$ Perhaps the audiences for Die Zauberflöte were indeed retreating from society into an imaginary space; but perhaps this escape was necessary to help the audience better understand their increasingly complex world. The opera is not merely moving from the real to the imaginary, or from the irrational to the rational; instead, it exposes the way in which the imaginary is imbedded in reality and the way in which the irrational is intertwined with the rational. The result is what Dolar describes as a "new synthetic myth-the myth about the Enlightenment itself" that integrates the Enlightenment and the stories of the gods. ${ }^{17}$ According to this model, not all magical figures must be banished along with superstition. Mozart invokes the mythological Persian god Zoroaster (and Zarathustra) in the character of Sarastro. He also incorporates the characters Orpheus and Eurydice into Tamino and Pamina. ${ }^{18}$ Likewise, it is not difficult to trace an allusion to the goddess Isis (and Demeter) in the Queen

16. Till, Mozart and the Enlightenment, 272.

17. Georg Friedrich Hegel describes in his Das älteste Systemprogramm that the new mythology provides a place of reason "where the enlightened and unenlightened can join hands." Quoted in Dolar Opera's Second Death, 81.

18. Till describes The Magic Flute as: "an Orphic story; a parable of the magic powers of art, and especially of music, to redeem humankind from its subjection to earthly nature, and ultimately to reunite humanity with the cosmos and restore harmony and bliss." Mozart and the Enlightenment, 317. 
of the Night. ${ }^{19}$ In these characters, Mozart and Schikaneder include both magical and mythical elements in the greater journey to Enlightenment reason. When magic and Enlightenment can coexist, so too can Tamino's self-discipline and Papageno's selfindulgence. Although Die Zauberflöte may seem on the surface to function as a progression from the dark to the light, the opera also demonstrates-through the characters of Papageno and the Queen of the Night-how the dark, or the irrational is never completely vanquished. Whereas the audiences of Der Stein leave the Theater and take with them the power of magic, the audiences of Die Zauberflote leave with the knowledge that words and music have the power to mend something within both the individual and the society.

The banishment of superstition does not yield Die Zauberflöte's pedagogical effect; after all, Papageno was never banished from Sarastro's realm. The opera also does not, as Maria Tatar proposes, debunk "magical thinking" and instill "the power embedded in language" in its place. ${ }^{20}$ Therefore, Die Zauberflöte does not operate according to the Enlightenment program of the "disenchantment of the world" that Theodor Adorno and Max Horkheimer describe in the The Dialectic of Enlightenment. ${ }^{21}$ Instead, the opera performs what Mary Hunter identifies as an "Enlightenment paradox," namely that "the ascendancy of Reason and the banishment of 'superstition' in public rhetoric went hand in hand with an increasing fascination with the irrational, the

19. Dolar, Opera's Second Death, 75-76.

20. Tatar, "Why Fairy Tales Matter," 57.

21. Theodor W. Adorno and Max Horkheimer, The Dialectic of Enlightenment, (New York: Verso NLB, 1979), 3. 
exotic, and the magic." 22 Hence, we must understand through Die Zauberflöte the way in which rationality and irrationality can be intertwined, so as to form a new and enlightened myth.

The stories of Der Stein and Die Zauberflöte are remarkably connected, but the two works diverge in both their music and in their overall effect. While the magical world of Der Stein leads a young prince to leadership and banishes superstition in the process, Die Zauberflöte provides its audience with an alternative: Tamino, too, sets out on a path to sovereignty, but the Enlightenment process in Die Zauberflöte does not banish superstition completely. Both Tamino and Pamina, as well as Papageno and Papagena, are permitted in Sarastro's realm, and so too is the paradoxical notion that the rational and the irrational can work hand in hand within an Enlightened world.

22. Mary Hunter, Mozart's Operas, A Companion, (New Haven: Yale University Press, 2008), 106. 


\section{Appendix}

Comparing Numbers from Der Stein der Weisen and Die Zauberflöte

Excerpt 1: The alla zoppa syncopations

Act II Overture (m. 1-6)

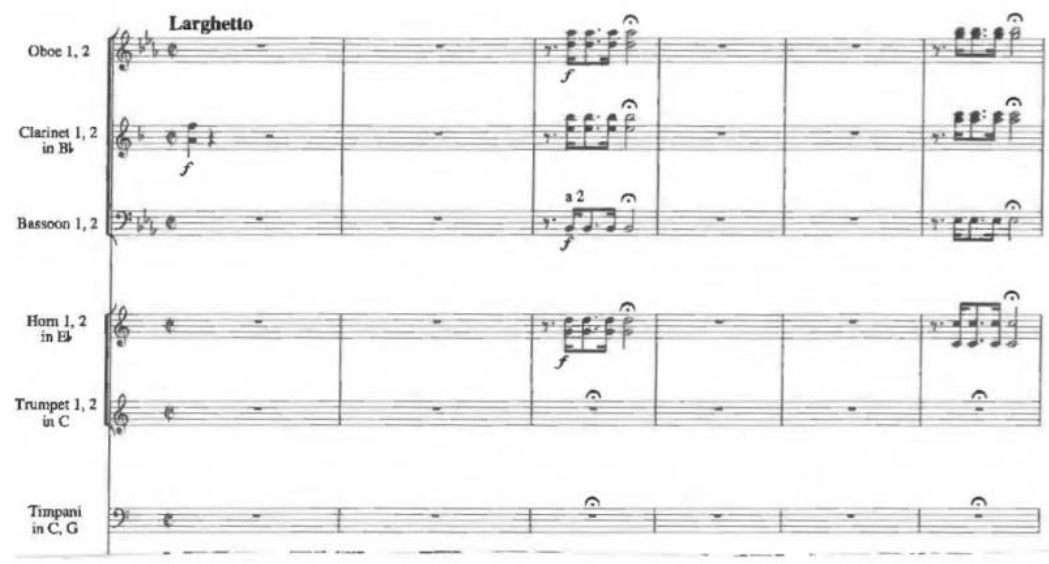

Act II Overture (m. 23-28)

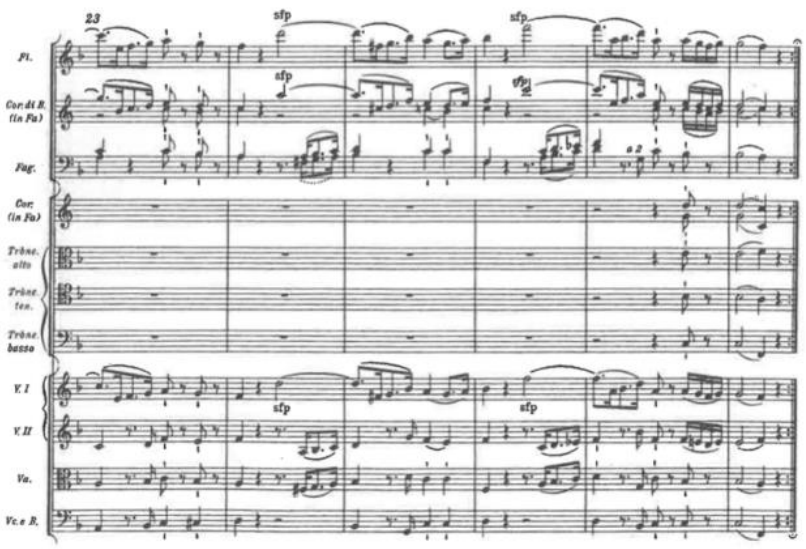


Excerpt 2a: Octave leaps: magic characters

Astromonte, Act I Finale (m. 506-513)

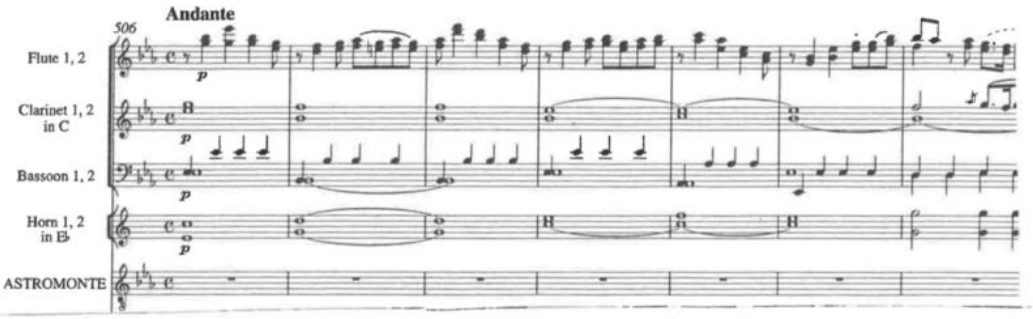

Königin, Act I, No. 4 Rec/Aria (m. 1-10)

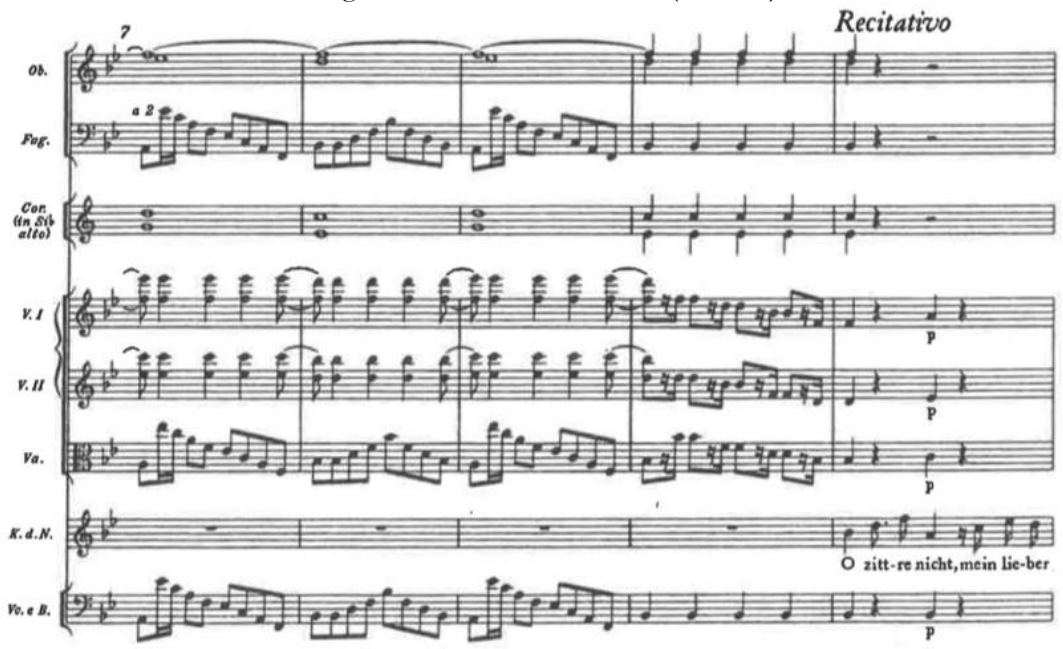


Excerpt 2b: Coloratura number

Astromonte Act I Finale (m. 542-580)

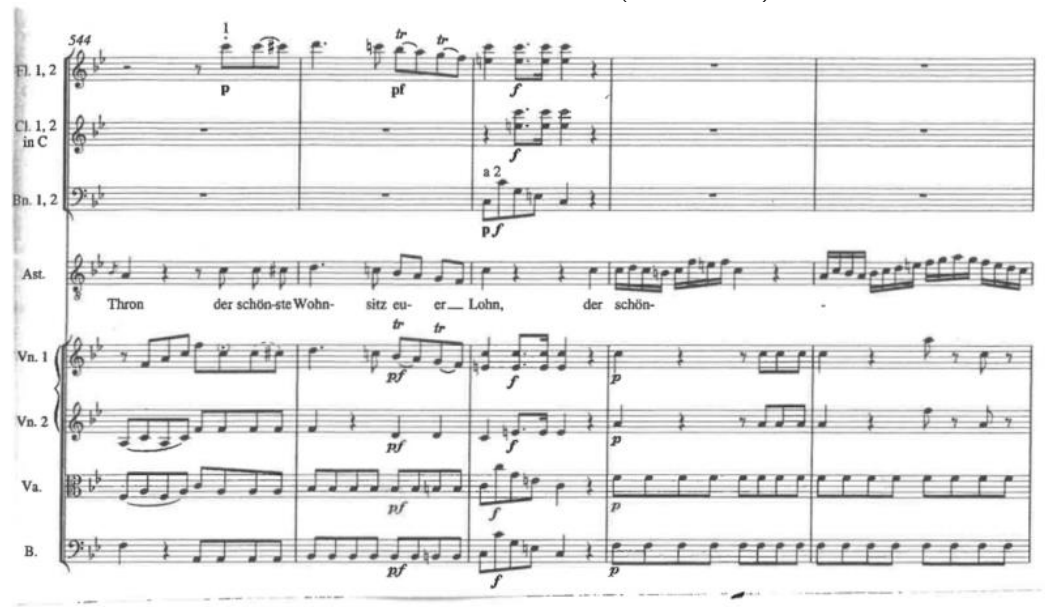

Königin, Act I, No. 4 Rec/Aria (m. 76-92)

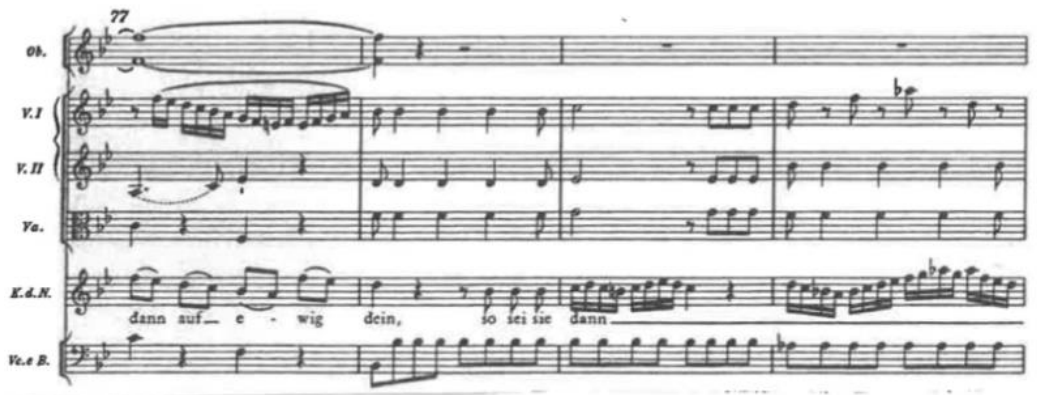




\section{Bibliography}

Adorno, Theodore W., and Max Horkheimer. "The Concept of

Enlightenment," in The Dialectic of Enlightenment. Edited by Gunzelin

Schmid Noerr. Translated by Edmund Jephcott. New York: Verso NLB, 1979.

Branscombe, Peter. Die Zauberflöte: Cambridge Opera Handbooks. Cambridge: Cambridge University Press, 1991.

Buch, David J. "Introduction" in Der Stein der Weisen. Edited by David J. Buch. Middleton: A-R Editions, 2007.

Buch, David J. Magic Flutes and Enchanted Forests: The Supernatural in EighteenthCentury Musical Theater. Chicago: University of Chicago Press, 2008.

Cairns, David. Mozart and His Operas. Berkeley: University of California Press, 2006.

Dolar, Mladen. "If Music Be the Food of Love," in Opera's Second Death. Edited by Slavoj Zizek and Mladen Dolar. Oxford: Routledge, 2002.

Mozart, Wolfgang Amadeus. Die Zauberflöte, KV 620. Basel: Bärenreiter Kassel, 2017.

Hunter, Mary. Mozart's Operas, A Companion. New Haven: Yale University Press, 2008.

Rosen, Charles. The Classical Style. New York: Norton, 1998.

Tatar, Maria. "Why Fairy Tales Matter: The Performative and the Transformative." Western Folklore 69:1 (2010). 55-64.

Till, Nicholas. Mozart and the Enlightenment. New York: Norton, 1996. 